Article

\title{
Pengaruh Laju Alir Umpan dan Arus Recycle Terhadap Proses Fermentasi Bioetanol Menggunakan Integrated Aerobic-Anaerobic Baffled Reactor (IAABR)
}

\author{
Margono*, Muhammad Azis Rigit Manfaat, Afianto Suryo Hutomo, Aida Nur Ramadhani \\ Program Studi Teknik Kimia, Fakultas Teknik, Universitas Sebelas Maret, Jl. Ir. Sutami 36A Surakarta, \\ Indonesia \\ E-mail: margono@ft.uns.ac.id
}

\begin{abstract}
Petroleum-based fuel is the main energy source used in the world. However, there is a future problem with the declined petroleum reserves. Therefore changing to alternative energy resource is a must. This research was to investigate the effects of feed and recycle flow-rate on bioethanol fermentation process using the integrated aerobic-anaerobic baffled reactor, especially on bioethanol production and sugar consumption. The start up process was run with a working volume of $25 \mathrm{~L}$ medium for 54 hours incubation. The recycled flow varried into $5 \mathrm{~L} / \mathrm{h}$ and $10 \mathrm{~L} / \mathrm{h}$ when the feed rate was $12.6 \mathrm{~L} / \mathrm{h}$. In other experiments, the feed flow rate was run at 5 and $12.6 \mathrm{~L} / \mathrm{h}$ when the recycle flow rate was $10 \mathrm{~L} / \mathrm{h}$. The broth samples were taken out periodically for measurements of bioethanol concentration, yeast population and residual sugar of consumptions. The experiments results in the highest bioethanol concentration of $14 \% \mathrm{v} / \mathrm{v}$ at the effluent of the reactor. It is higher from the process without recycling of the process medium. Nevertheless, no differential effect of the recycle flow-rate of $5 \mathrm{~L} / \mathrm{h}$ and $10 \mathrm{~L} / \mathrm{h}$ on the bioethanol production.
\end{abstract}

Keywords: Bioethanol, Baffled Reactor, Feed, Recycle

EQUILIBRIUM Volume 3 No.1 July 2019

Online at http:/ / equilibrium.ft.uns.ac.id 


\section{Pendahuluan}

Kebutuhan dan konsumsi masyarakat akan bahan bakar berbasis minyak bumi (BBM) yang semakin meningkat berbanding terbalik dengan ketersediaannya. Pada tahun 2014 produksi minyak bumi mencapai 288 juta barel dan diperkirakan terus menurun menjadi 52 juta barel tahun 2050 [1]. Pada data tersebut menunjukan bahwa BBM (bensin, minyak solar, minyak bakar, minyak tanah dan avtur) masih mendominasi kebutuhan energi nasional dengan pangsa 32\% di tahun 2014. Salah satu upaya untuk mengurangi konsumsi masyarakat terhadap BBM adalah dengan memanfaatkan energi terbarukan berbasis nabati atau sering disebut bahan bakar nabati (BBN)[2]. Bioetanol merupakan salah satu jenis BBN yang mudah diproduksi dengan biaya yang terjangkau.

Bioetanol memiliki beberapa kelebihan, diantaranya sifat bioetanol yang dapat diperbarui dan ramah lingkungan karena emisi karbondioksida rendah. Bioetanol diproduksi dengan cara fermentasi. Salah satu bahan baku fermentasi yang murah dan mudah didapatkan adalah molasses. Molasses merupakan limbah pabrik gula pasir yang tidak dapat lagi dikristalkan. Molasses mengandung sejumlah besar gula, baik sukrosa maupun gula reduksi yang totalnya berkisar antara $48-56 \%$. Mikroorganisme yang umumnya digunakan dalam proses produksi bioetanol adalah Saccharomyces cerevisiae. S. cerevisiae memiliki beberapa kelebihan diantaranya mudah beradaptasi dengan lingkungan, lebih tahan terhadap kadar alkohol tinggi, dan lebih mudah didapat [3].

Secara umum sistem produksi bioetanol dapat dilakukan secara batch maupun kontinyu. Sistem kontinyu memiliki keunggulan diantaranya mengurangi efek inhibitor pada sel karena akumulasi bioetanol. Pada sistem produksi bioetanol kontinyu, laju alir umpan sangat berpengaruh terhadap hasil fermentasi. Jika laju alir umpan terlalu besar, maka dapat terjadi wash-out pada sel dalam fermentor sehingga produksi bioetanol menjadi tidak optimal. Selain itu, peran recycle pada fermentor juga tidak kalah krusial. Recycle sel yang mana menjaga agar sel penghasil bioetanol tetap dalam fermentor dapat menjadi jalan untuk menjaga jumlah sel dalam fermentor tetap tinggi [4].

Optimasi dalam pembuatan bioetanol sudah banyak dilakukan. Reaktor jenis Continous Stirred Tank Reactor (CSTR) dan Immobilized Cell Reactor (ICR) paling banyak menjadi dasar sistem fermentor yang digunakan pada fermentasi. Ada beberapa modifikasi sistem fermentor yang dapat digunakan yaitu sistem reaktor dengan sel terimobilisasi, two-tank system dengan recycle sel, dan juga anaerobic baffled reactor (ABR)[5].

ABR cukup potensial karena konstruksinya sederhana, instrumentasi yang mudah, dan mampu memberikan waktu retensi sel yang lama. Desain reaktor ABR dapat meminimalkan efek racun dari bioetanol dan meningkatkan perlindungan terhadap sel dari goncangan (perubahan yang mendadak) kondisi operasi seperti $\mathrm{pH}$, suhu, dan muatan organik. Hal ini dapat terjadi karena ABR terbagi menjadi beberapa kompartemen, sehingga perubahan pada satu kompartemen tidak serta merta menjadi perubahan pada kompartemen yang lain.

Penelitian sebelumnya menunjukkan bahwa reaktor ABR yang dimodifikasi dengan mengintegrasikannya dengan proses aerobik dapat meningkatkan produktivitas bioetanol. Jenis reaktor ini kemudian dikenal dengan nama Integrated Aerobic-Anaerobic Baffled Reactor (IAABR). Namun demikian, proses aliran fluida dalam IAABR masih cukup rendah sehingga masih dimungkinkan untuk peningkatan laju alir fluida dalam reaktor agar distribusi sel mengalami peningkatan dan diharapkan produktivitas mengalami peningkatan juga. Penelitian ini dimaksudkan untuk mempelajari pengaruh arus recycle pada proses fermentasi bioetanol menggunakan Integrated Aerobic-Anaerobic Baffled Reactor (IAABR). Laju alir arus recycle dan arus umpan dipelajari terhadap pengaruhnya pada konsumsi substrat gula, konsentrasi sel, dan kadar bioetanol dalam reaktor.

\section{Bahan dan Metode Penelitian}

\subsection{Mikroorganisme dan media pertumbuhan}

Kultur mikroorganisme berupa $S$. cerevisiae yang diperoleh dari ragi kering komersial fermiol. Media pertumbuhan dibedakan menjadi 2, yaitu media inokulum dan media produksi. Media inokulum 1 mengandung 2,5 g/l yeast extract, $10 \mathrm{~g} / 1$ glukosa anhidrat, $0,12 \mathrm{~g} / 1 \mathrm{MgSO}_{4}, 1,3 \mathrm{~g} / 1 \mathrm{NH}_{4} \mathrm{Cl}$, dan $0,06 \mathrm{~g} / \mathrm{l}$ $\mathrm{CaCl}_{2} \cdot 2 \mathrm{H}_{2} \mathrm{O}$. Media produksi berupa larutan molasses $30 \% \mathrm{w} / \mathrm{w}$. Media inokulum 2 sama dengan media produksi, yaitu larutan molasses $30 \% \mathrm{w} / \mathrm{w}$. 


\subsection{Pengembangan Inokulum}

Inokulum dikembangkan dalam 2 langkah, yaitu $50 \mathrm{ml}$ inokulum 1 disiapkan menggunakan media inokulum dalam erlenmeyer $100 \mathrm{ml}$ dan inokulum 2 berupa $450 \mathrm{ml}$ media produksi dalam erlenmeyer ukuran $1000 \mathrm{ml}$. Lima miligram ragi kering ditambahkan pada inokulum 1 dan diinkubasi dalam incubator shaker pada $100 \mathrm{rpm}$ dan $30{ }^{\circ} \mathrm{C}$ selama 24 jam. Media inokulum 2 yang sudah steril diinokulasi dengan $50 \mathrm{ml}$ inokulum 1 dan diinkubasi dalam incubator shaker pada $30^{\circ} \mathrm{C}$ dengan kecepatan $100 \mathrm{rpm}$ selama 48 jam.

\subsection{Fermentasi Produksi}

Satu set alat fermentasi yang terdiri atas IAABR, tangki umpan, pemanas, aerator (kompresor dan pengaduk), pompa recycle, dan tangki produk dirangkai seperti Gambar 1. Inokulum 2 diinokulasikan ke dalam kompartemen A1 yang sudah diisi dengan 24,5 liter media produksi, kemudian diinkubasi secara aerobik selama 54 jam pada $30{ }^{\circ}$ C. Selesai diinkubasi secara batch pada jam ke 54, media produksi yang sudah disiapkan dalam tangki umpan dialirkan secara kontinyu sesuai dengan kecepatan alir yang sudah ditentukan (5 dan 12,6 liter/jam). Ketika seluruh volume IAABR telah berisi media produksi maka pompa recycle diaktifkan dan proses fermentasi kontinyu tersebut dijalankan selama 246 jam. Suhu inkubasi dijaga pada 30 ${ }^{\circ} \mathrm{C}$ dan sampling dilakukan pada setiap kompartemen secara berkala (6 atau 18 jam) untuk pemeriksaan kadar gula sisa, sel, dan bioetanol sebanyak 2x ulangan.

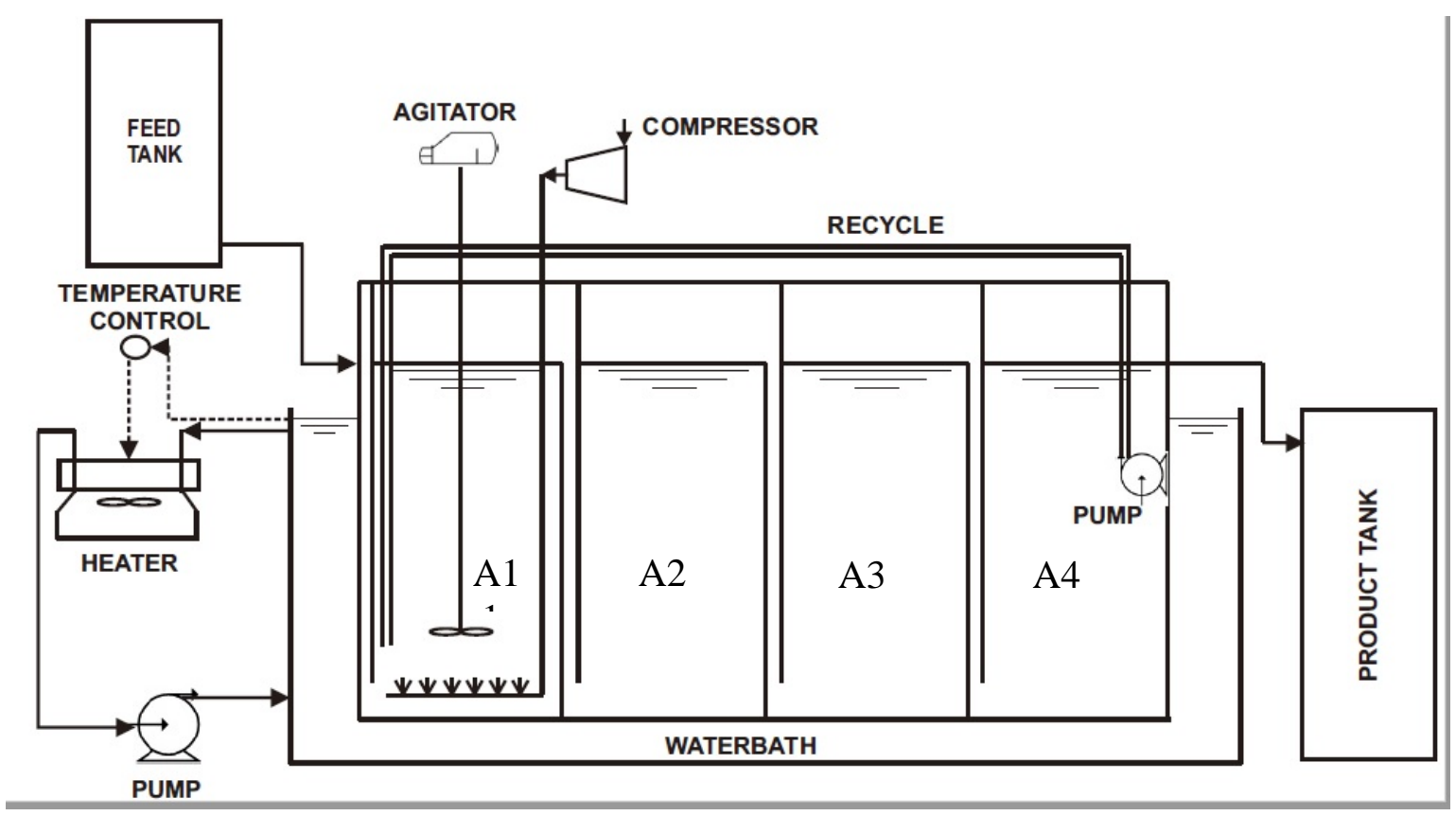

Gambar 1. Sistem Integrated Aerobic-Anaerobic Baffled Reactor (IAABR)

\subsection{Analisa Kadar Sel, gula sisa, dan bioetanol}

Konsentrasi gula total (gula sisa) diukur dengan metode fenol-asam sulfat (Dubois dkk., 1956). Sebelum dianalsis, sampel diencerkan sebanyak 10 kali pengenceran untuk mencapai kisaran pembacaan spektrofotometer. Dua mililiter sampel ditambahkan ke dalam tabung reaksi, kemudian dtambahkan $0,1 \mathrm{ml}$ larutan fenol 80\% dilanjutkan dengan $5 \mathrm{ml}$ asam sulfat pekat. Larutan dihomogenkan menggunakan vortex agitator dan diinkubasi dalam incubator shaker selama 30 menit. Selanjutnya larutan analisis dibaca adsorbansinya dengan spektrofotometer pada panjang gelombang $490 \mathrm{~nm}$. Hasil pembacaan adsorbansi dikonversi menjadi konsentrasi gula total menggunakan grafik standar yang sudah disiapkan sebelumnya.

Konsentrasi sel dihitung menggunakan counting chamber haemacytometer. Sampel diencerkan lebih dulu agar sel saling terpisah dan dapat dihitung menggunakan mikroskop. Sampel diambil menggunakan mikropippet sebanyak 0,1 ml dan diteteskan ke counting chamber serta ditutup dengan gelas objek. Pembacaan dilakukan menggunakan mikroskop dengan perbesaran 400X - 1000X. 
Konsentrasi bioetanol diukur dengan metode densitimeter menggunakan piknometer. Setiap $10 \mathrm{ml}$ sampel diencerkan dengan akuades kemudian didistilasi hingga hampir habis. Distilat yang dihasilkan diukur massa jenisnya menggunakan piknometer. Hasil pengukuran massa jenis dikonversi menjadi konsentrasi bioetanol menggunakan bantuan Tabel 2.112. Densities of Aquous Organic Solution-Ethyl Alcohol dalam Perry's Chemical Engineer's Handbook.

\section{Hasil dan Pembahasan}

\subsection{Pengaruh laju alir recycle pada proses fermentasi}

Awal dari percobaan dioperasikan secara batch selama 54 jam dengan tujuan untuk mengembangkan sel agar sel menjadi lebih kuat dan mencapai konsentrasi yang cukup untuk beroperasi secara kontinyu. Hanya saja proses start up secara batch tidak dipelajari dalam penelitian ini. Proses secara kontinyu dimulai dari jam ke 54 setelah inkubasi awal. Proses recycle dilakukan dengan pemompaan dari kompartemen A4 ke A1 dengan 2 variasi laju alir, yaitu $5 \mathrm{~L} / \mathrm{j}$ dan $10 \mathrm{~L} / \mathrm{j}$. Percobaan variasi laju recycle dilakukan untuk laju umpan sebesar 12,6 $\mathrm{L} / \mathrm{j}$. Hasil percobaan berupa pengaruh laju alir recycle terhadap kadar bioetanol disajikan pada Gambar 2.
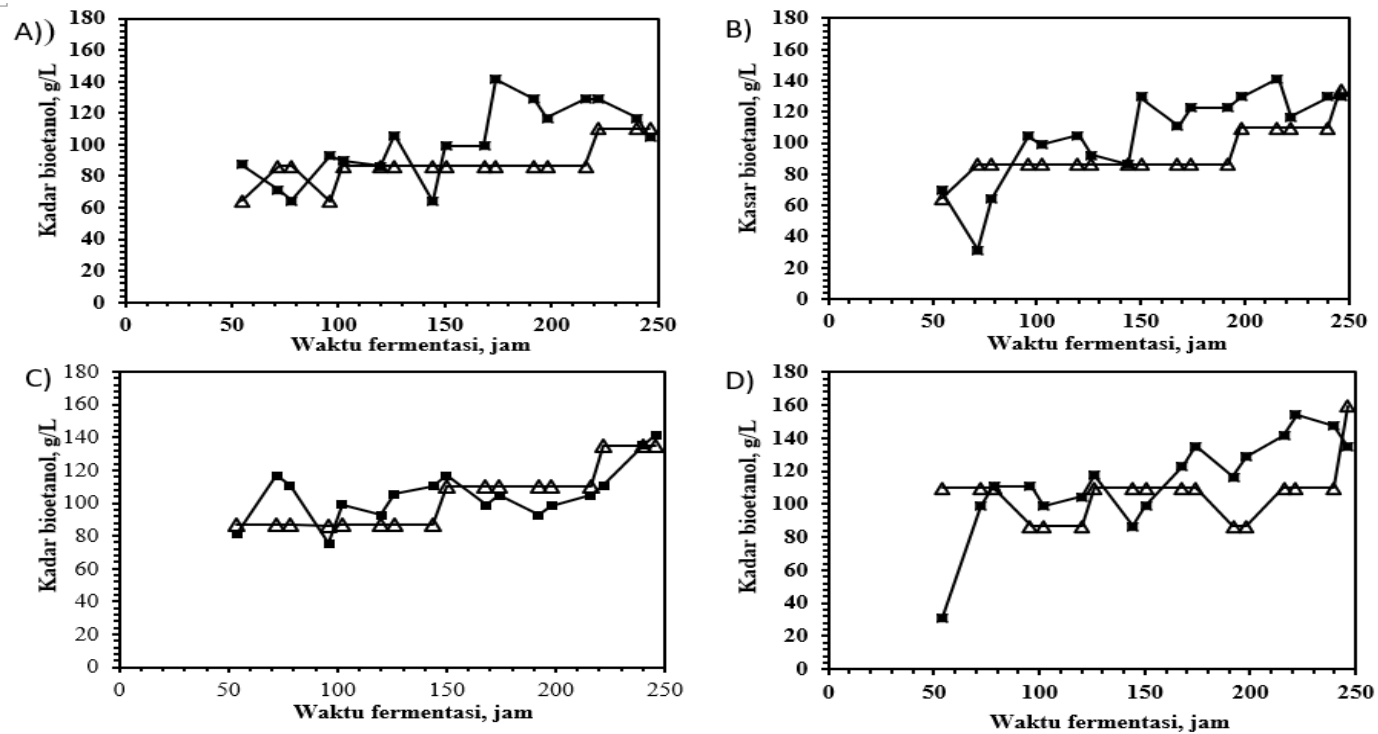

Gambar 2 . Pengarug Laju Alir Recycle Terhadap Kadar Bioetanol pada Laju alir Umpan 12,6 L/j (A: kompartemen A1, B: kompartemen A2, C: kompartemen A3, D: kompartemen A4 ; $\mathbf{q}$ : laju recycle $5 \mathrm{~L} / \mathrm{j}, \Delta$ : laju recycle $10 \mathrm{~L} / \mathrm{j})$.

Gambar 2 menunjukkan bahwa kadar bioetanol yang didapatkan cukup fluktuatif dalam setiap kompartemennya. Akan tetapi kadar bioetanol antar kompartemen hampir mirip satu sama lain. Artinya, laju alir recycle $5 \mathrm{~L} / \mathrm{j}$ dan $10 \mathrm{~L} / \mathrm{j}$ sudah cukup mendistribusikan komponen-komponen yang ada dalam media dalam setiap komponen. Kadar bioetanol rata-rata 2 data terakhir masing-masing adalah 14,1\% untuk laju recycle 5 $\mathrm{L} / \mathrm{j}$ dan $13,9 \%$ untuk laju $10 \mathrm{~L} / \mathrm{j}$ atau perbedaan rata-rata keduanya adalah $0,1 \%$. Perbedaan yang cukup kecil tersebut menunjukkan bahwa laju recyle $5 \mathrm{~L} / \mathrm{j}$ dan $10 \mathrm{~L} / \mathrm{j}$ tidak memiliki dampak yang berbeda pada proses fermentasi secara kontinyu. Fenomena lain yang dapat diamati adalah bahwa kadar bioetanol cenderung selalu meningkat dari waktu ke waktu. Data ini menunjukkan bahwa dalam waktu fermentasi 246 jam operasi belum menampakkan kadar bioetanol yang ajeg (steady state). Kondisi yang belum steady state ini juga terkonfirmasi oleh data-data lain, yaitu populasi sel dan kadar gula sisa. Kadar bioetanol meningkat seiring dengan menurunnya konsentrasi gula sisa.

Profil kepadatan populasi sel terhadap waktu yang dipengaruhi oleh laju alir recycle disajikan pada Gambar 3. Profil ini menampilkan semua populasi sel pada laju alir umpan $5 \mathrm{~L} / \mathrm{j}$ dan $10 \mathrm{~L} / \mathrm{j}$ di setiap kompartemen reaktor, baik kompartemen A1, A2, A3, dan A4. Populasi sel mengalami peningkatan di setiap kompartemen selama fermentasi baik pada laju recycle $5 \mathrm{~L} / \mathrm{j}$ maupun $10 \mathrm{~L} / \mathrm{j}$.

Gambar 3 menunjukkan profil yang sama antara di setiap kompartemen antara laju recycle $5 \mathrm{~L} / \mathrm{j}$ dan $10 \mathrm{~L} / \mathrm{j}$. Peningkatan populasi sel memiliki kecenderungan (tren) yang sama antara laju recycle $5 \mathrm{~L} / \mathrm{j}$ dan 10 $\mathrm{L} / \mathrm{j}$ pada semua kompartemen. Sebagaimana fenomena pada kadar bioetanol, populasi sel di seiap 
kompartemen menunjukkan belum terjadi operasi fermentasi steady state karena belum ada populasi yang cenderung konstan. Kepadatan populasi sel hampir sama antara kompartemen satu dengan lainnya, artinya bahwa laju recycle $5 \mathrm{~L} / \mathrm{j}$ dan $10 \mathrm{~L} / \mathrm{j}$ memberikan efek pengadukan yang baik sehingga mampu memberikan distribusi komposisi yang cukup baik ke semua posisi reaktor. Populasi sel akhir rata-rata pada proses dengan laju recycle $10 \mathrm{~L} / \mathrm{j}$ adalah $(2,63 \pm 0,09) \times 10^{8} \mathrm{sel} / \mathrm{mL}$. Adapun populasi sel akhir rata-rata pada proses dengan laju recycle $5 \mathrm{~L} / \mathrm{j}$ adalah $(1,5+0,08) \times 10^{8} \mathrm{sel} / \mathrm{mL}$.
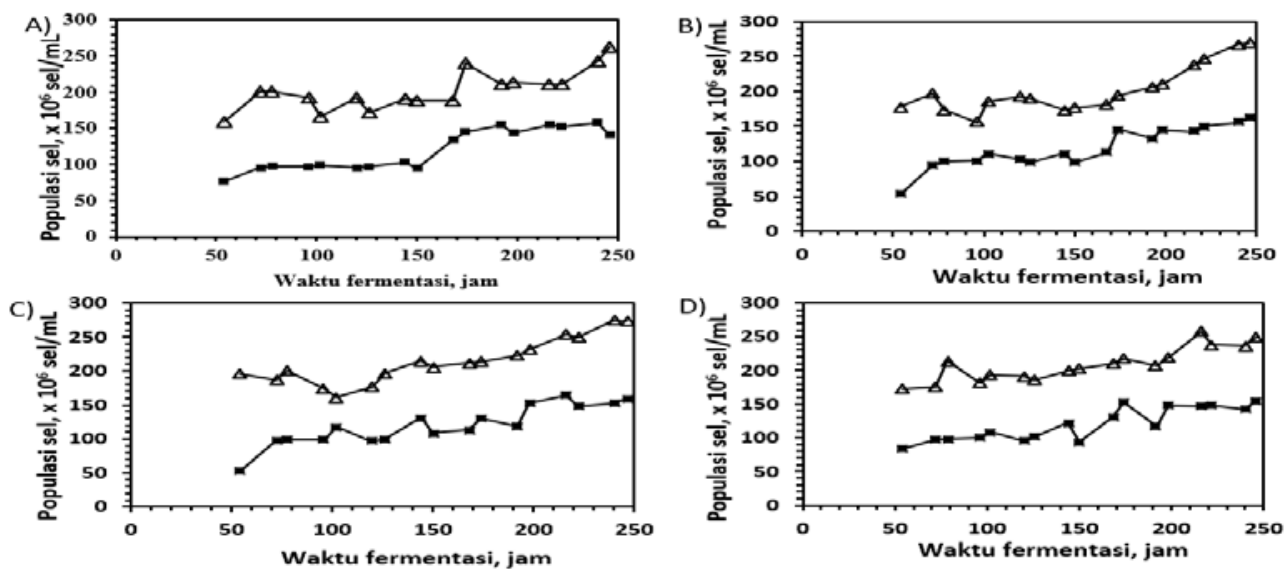

Gambar 3. Profil Populasi Sel Selama Fermentasi dengan laju umpan 12,6 L/j (A: kompartemen A1, B: kompartemen A2, C: kompartemen A3, D: kompartemen A4 ; : laju recycle $5 \mathrm{~L} / \mathrm{j}, \Delta$ : laju recycle $10 \mathrm{~L} / \mathrm{j}$ )

Gambar 4 menyajikan profil konsumsi gula total di seluruh kompartemen reaktor. Profil kadar gula sisa tersebut menunjukkan bahwa proses fermentasi belum menunjukkan beroperasi pada kondisi steady state. Kondisi ini telah dikonfirmasi pada profil kadar bioetanol (Gambar 2) dan profil kepadatan populasi sel (Gambar 3). Jika dibandingkan antara profil kadar gula sisa di setiap kompartemen maka terlihat bahwa ada kemiripan profil antar kompartemen untuk laju recycle yang sama.
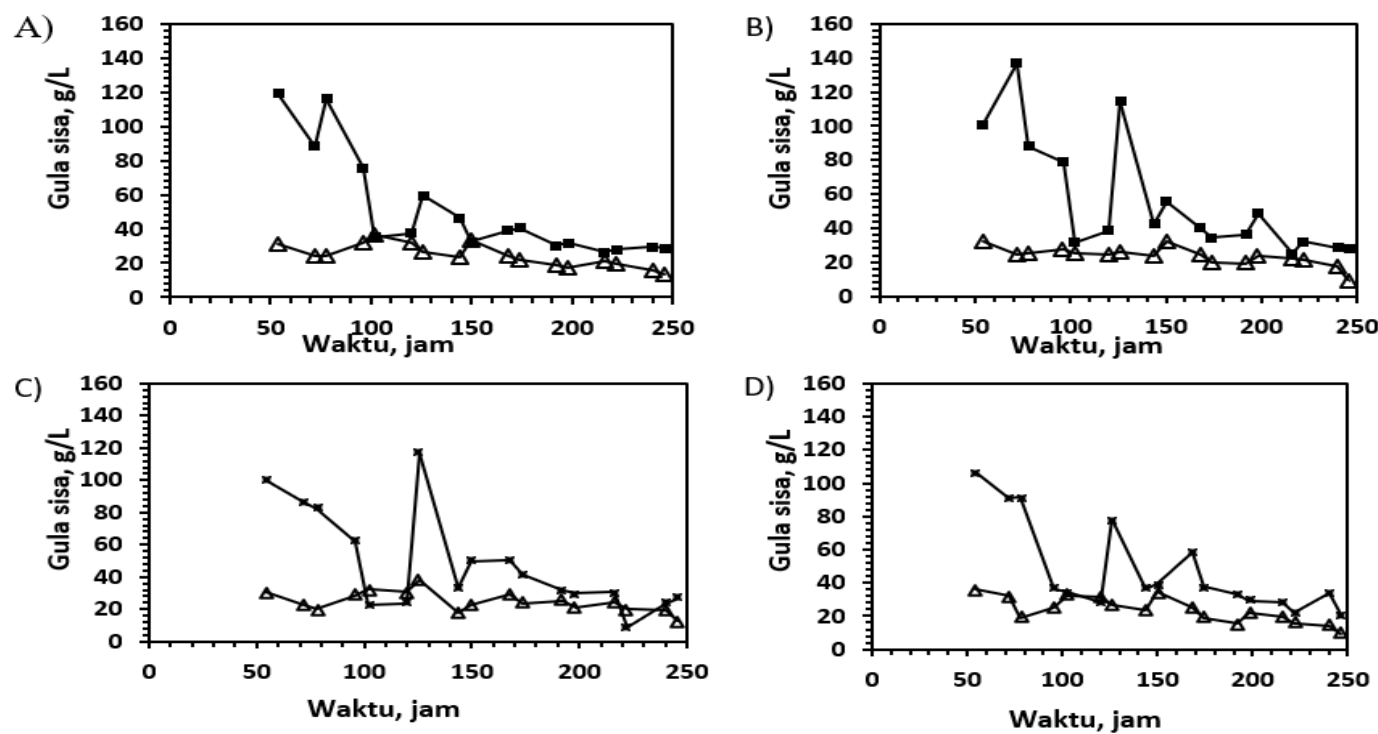

Gambar 4 . Profil Gula Sisa di Setiap Kompartemen Reaktor dengan Laju Umpan 12,6 L/j (A: kompartemen A1, B: kompartemen A2, C: kompartemen A3, D: kompartemen A4 ; $\mathrm{L} / \mathrm{j})$. 


\subsection{Pengaruh Laju Alir Umpan pada Fermentasi Bioetanol}

Percobaan untuk mempelajari pengaruh laju umpan pada proses kontinyu dilakukan dengan laju recycle $10 \mathrm{~L} / \mathrm{j}$. Adapun laju alir umpan yang dipelajari adalah $5 \mathrm{~L} / \mathrm{j}$ dan 12,6 L/j. Parameter proses fermentasi yang digunakan sama antara pengaruh laju alir recycle dengan laju alir umpan, yaitu kadar bioetanol di setiap kompartemen reaktor, kepadatan populasi sel di setiap kompartemen reaktor, dan profil gula sisa di setiap kompartemen reaktor. Pengaruh laju umpan terhadap kadar bioetanol selama proses fermentasi disajikan pada Gambar 5.
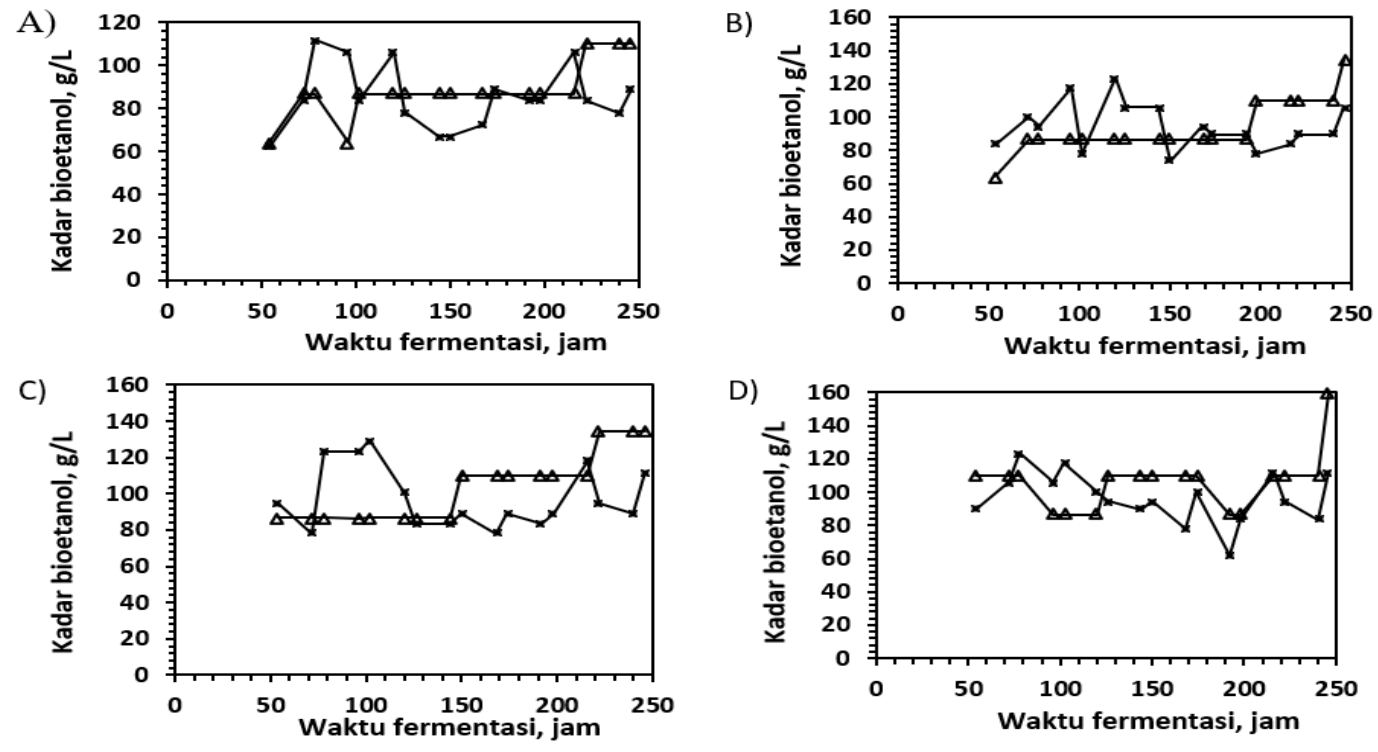

Gambar 5 . Kadar bioetanol selama proses fermentasi di setiap kompartemen reaktor (A: kompartemen A1, B: kompartemen A2, C: kompartemen A3, D: kompartemen A4 ; : laju umpan 5 $\mathrm{L} / \mathrm{j}, \Delta$ : laju umpan 12,6 L/j).

Profil kadar bioetanol dalam Gambar 5 menunjukkan bahwa kadar bioetanol mengalami fluktuasi yang tidak teratur. Dalam kompartemen akhir (A4) terlihat bahwa kadar bioetanol pada laju umpan 12,6 L/j relatif lebih tinggi dibandingkan dengan kadar bioetanol pada laju umpan $5 \mathrm{~L} / \mathrm{j}$. Hal ini berarti bahwa dengan laju alir recycle $10 \mathrm{~L} / \mathrm{j}$ cukup memberikan efek peningkatan pada kadar bioetanol produk dan kapasitas produksi pada proses fermentasi menggunakan IAABR. Proses produksi bioetanol menggunakan IAABR tanpa arus recycle menghasilkan produk dengan kadar bioetanol 5,7\% [6]. sedangkan dalam percobaan ini mengalami peningkatan menjadi 14\%. Berdasarkan literatur yang sama, laju umpan fermentasi kontinyu dengan IAABR tanpa arus recycle adalah sebesar 3,75 L/j dan pada percobaan ini meningkat menjadi $12,6 \mathrm{~L} / \mathrm{j}$. Dengan demikian ada peningkatan kapasitas pengolahan umpan sebesar 8,85 L/j.

Parameter berikutnya adalah populasi sel dalam reaktor di setiap kompartemen. Profil populasi sel di setiap kompartemen reaktor disajikan pada Gambar 6. Sebagaimana sudah dijelaskan sebelumnya, populasi sel juga dimonitor hanya setelah proses fermentasi kontinyu berlangsung, yaitu 54 jam setelah inokulasi awal sampai jam ke 246. Ada perbedaan yang nampak pada profil populasi sel di setiap kompartemen antara laju umpan $5 \mathrm{~L} / \mathrm{j}$ dengan 12,6 L/j. Populasi sel pada laju umpan $5 \mathrm{~L} / \mathrm{j}$ mengalami penurunan di setiap kompartemen, sedangkan untuk laju umpan 12,6 L/j tampak bahwa populasi sel mengalami kenaikan di setiap kompartemen reaktor. Artinya, laju umpan media sebesar 12,6 L/j memberikan input substrat gula yang lebih cepat dari yang diperlukan sehingga sel tumbuh lebih cepat dari pada kematiannya. Juga, pertumbuhan sel pada laju umpan 12,6 L/j lebih cepat dari terjadinya wash out atau mungkin belum terjadi wash out. Kondisi sebaliknya terjadi pada laju umpan $5 \mathrm{~L} / \mathrm{j}$. 

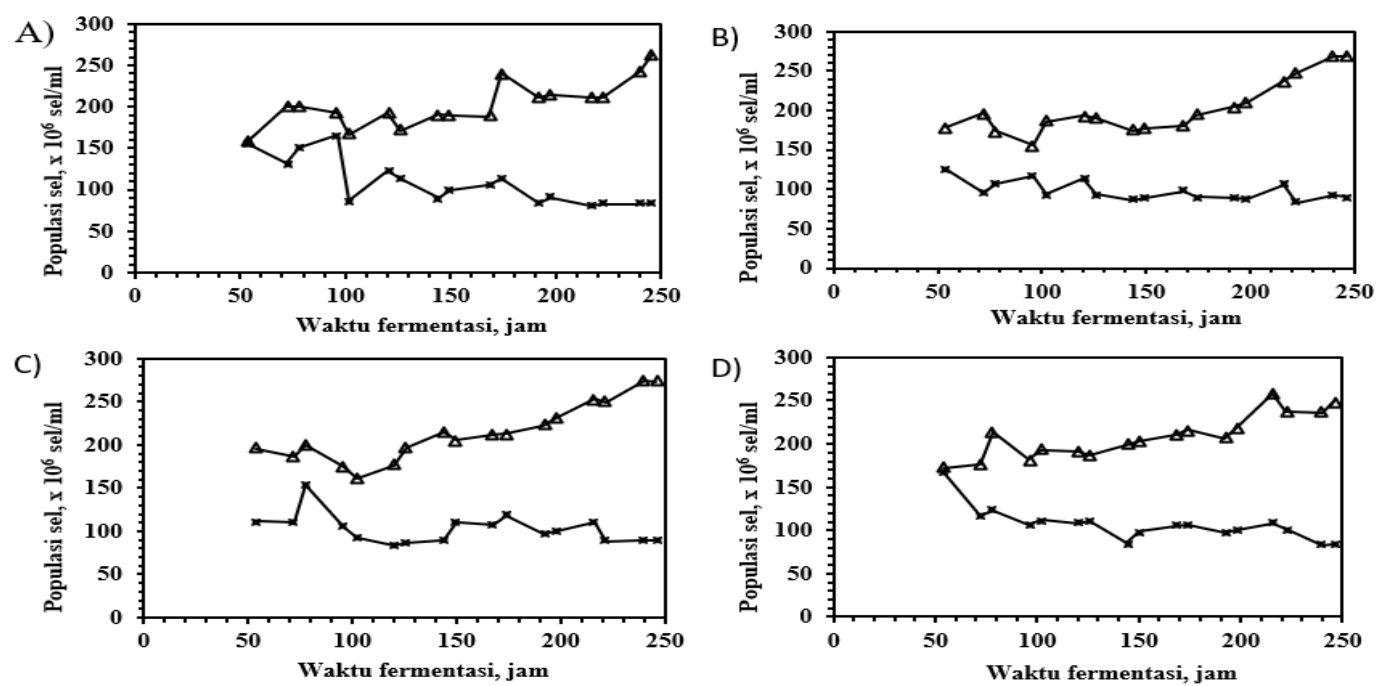

Gambar 6 . Profil populasi sel di setiap kompartemen akibat variasi laju umpan (A: kompartemen A1, B: kompartemen A2, C: kompartemen A3, D: kompartemen A4 ;

: laju umpan $5 \mathrm{~L} / \mathrm{j}, \Delta$ : laju umpan 12,6 $\mathrm{L} / \mathrm{j})$.

Profil konsumsi gula ditunjukkan dalam ukuran gula sisa yang dikonsumsi oleh sel yeast. Kadar gula sisa disajikan dalam profil gula sisa di setiap kompartemen reaktor pada Gambar 7. Ada persamaan kecenderungan profil gula sisa antara proses fermentasi dengan laju umpan $5 \mathrm{~L} / \mathrm{j}$ dengan $12,6 \mathrm{~L} / \mathrm{j}$. Baik profil gula sisa pada laju umpan $5 \mathrm{~L} / \mathrm{j}$ maupun $12,6 \mathrm{~L} / \mathrm{j}$ sama-sama mengalami penurunan kadar gula sisa dari waktu ke waktu di seluruh waktu fermentasi. Hal ini berarti bahwa untuk kedua laju umpan tersebut memberikan tambahan gula umpan yang lebih besar dari kebutuhan untuk pertumbuhan sel dan produksi bioetanol yang dilakukan oleh S. cerevisiae. Sebagaimana sudah dikonfirmasi pada data produksi bioetanol dan populasi sel dalam media maka fenomena ini memastikan belum terjadinya proses yang berlangsung secara steady state dalam waktu 246 jam fermentasi.
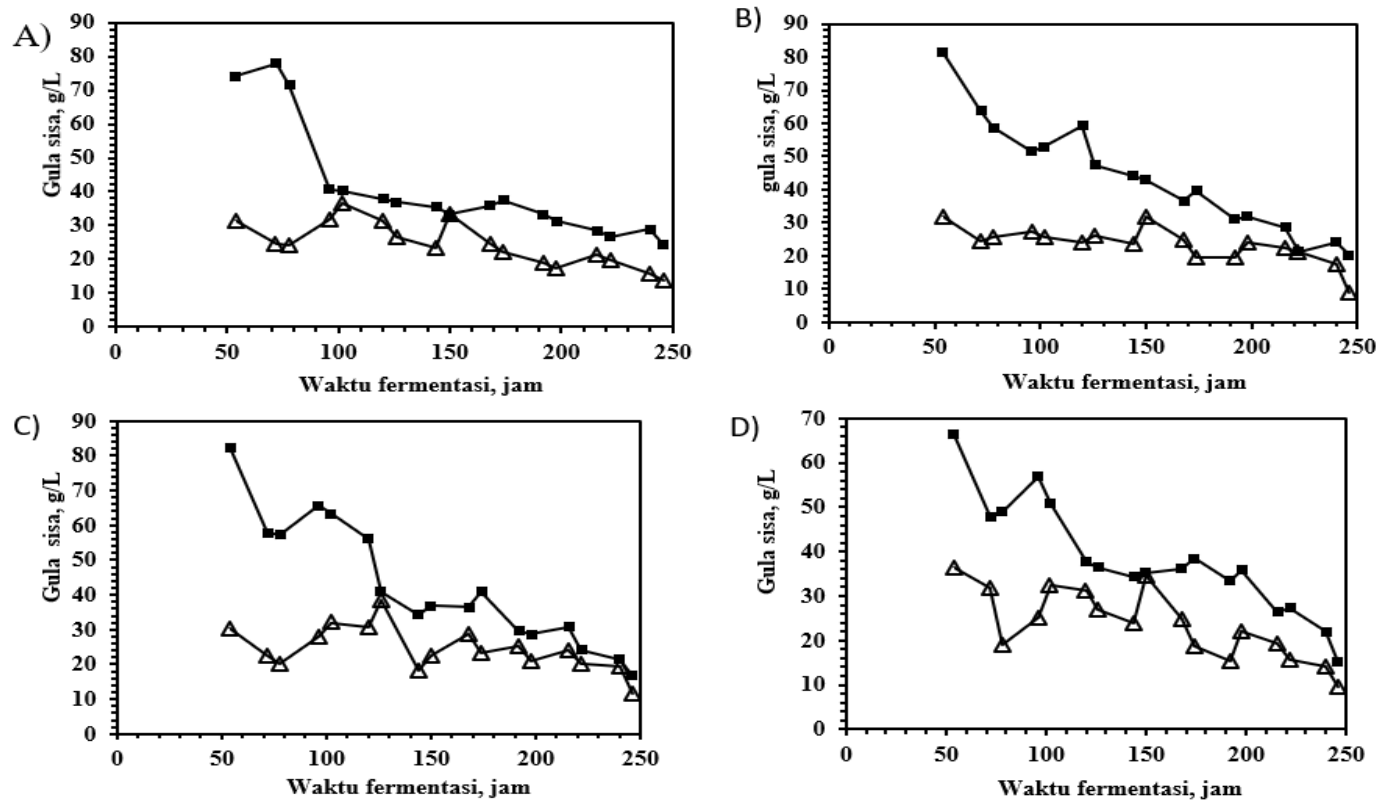

Gambar 7 . Kurva Kandungan Gula Sisa (A: kompartemen A1, B: kompartemen A2, C: kompartemen A3, D: kompartemen A4; : laju umpan $5 \mathrm{~L} / \mathrm{j}, \Delta$ : laju umpan $12,6 \mathrm{~L} / \mathrm{j})$.) 
Profil gulas sisa dengan laju umpan $12,6 \mathrm{~L} / \mathrm{j}$ lebih landai dibandingkan dengan laju umpan $5 \mathrm{~L} / \mathrm{j}$. Hal ini sebanding dengan profil pertumbuhan sel yang terjadi (Gambar 6). Artinya bahwa konsumsi gula oleh sel untuk pertumbuhan pada laju umpan 12,6 L/j lebih tinggi dibandingkan dengan laju konsumsi gula pada laju umpan $5 \mathrm{~L} / \mathrm{j}$. Fenomena ini dijelaskan oleh capaian kadar bioetanol yang hampir sama dalam proses fermentasi dengan kedua laju umpan tersebut.

\section{Kesimpulan}

Fenomena yang ditunjukkan oleh 3 parameter proses, kadar bioetanol, populasi sel, dan profil gula sisa, menunjukkan belum tercapai proses fermentasi steady state dalam waktu 246 jam proses. Adanya proses recycle pada arus media mampu meningkatkan kadar bioetanol yang dihasilkan, yaitu 14\% rata-rata untuk dua laju recycle dibandingkan dengan 6,3\% pada proses tanpa recycle. Produktivitas bioetanol dengan arus recycle lebih tinggi dibandingkan dengan proses tanpa recycle. Ada 2 indikasi dalam hal ini, yaitu laju umpan yang lebih cepat pada proses dengan recycle $(12,6 \mathrm{~L} / \mathrm{j}$ dibandingkan 3,75 L/j) dan kadar bioetanol di kompartemen akhir reaktor (bioetanol hasil produksi) lebih tinggi pada proses dengan arus recycle. Namun demikian, pengaruh laju arus recycle $5 \mathrm{~L} / \mathrm{j}$ dengan $10 \mathrm{~L} / \mathrm{j}$ hampir mirip pada semua parameter yang dipelajari. Jadi dapat disimpulkan bahwa laju arus recycle $5 \mathrm{~L} / \mathrm{j}$ sudah cukup memperbaiki proses tanpa recycle, dan penambahan laju recycle menjadi $12,6 \mathrm{~L} / \mathrm{j}$ tidak memberikan perbaikan proses lebih lanjut.

\section{Referensi}

[1] Badan Pengkajian dan Penerapan Teknologi, "Outlook Energi Indonesia 2016”, Pusat Teknologi Pengembangan Sumber Daya Energi (PTSE), Jakarta, 2015

[2] Republik Indonesia, "Peraturan Presiden No. 5 Tahun 2006 tentang Kebijakan Energi Nasional", Lembaran Negara RI Tahun 2006, Sekertariat Negara, Jakarta, 2006

[3] Azizah, N., A.N. Al-Baarri, dan S. Mulyani, "Pengaruh Lama Fermentasi terhadap Kadar Alkohol, pH dan Produksi Gas pada Proses Fermentasi Bioetanol dari Whey dengan Substitusi Kulit Nanas," Jurnal Aplikasi Teknologi Pangan, vol. 1, no. 2, 2012.

[4] Alexandre, H., V.Ansanay-Galeote, S. Dequin, and B. Blonding, "Global Gene Expression during Short-Term Ethanol Stress in Saccharomyces Cerevisiae," FEBSLetters, vol. 498, no. 1, pp. 98-103, 2001.

[5] Margono, I. Khotimah, D. J. Risantono, M. Kaavessina, and E. R. Dyartanti, "The Performance of Start-Up Process in Continuous Ethanol Production Using Integrated Aerobic-Anaerobic Baffled Reactor" Advance Science Letters, vol. 23, pp. 5815-18, 2017.

[6] Margono, Mujtahid Kaavessina, dan Endah Retno Dyartanti, "Performance investigation of a pilot scale integrated aerobic-anaerobic baffle reactor for continuous ethanol production process under various sugar feeding-rates," Energy Exploration Exploitation, vol. 36, no. 1, pp. 149-165, 2017. 